\title{
SELF-REPORTED PHYSICAL FUNCTIONING AND FACTORS ASSOCIATED WITH IT AMONG HIV INFECTED ADULTS ON ANTIRETROVIRAL TREATMENT AT THE UNIVERSITY OF GONDAR HOSPITAL, ETHIOPIA
}

\author{
Mulugeta Bayisa*, Mamo Wubshet** \\ Corresponding author: Mamo Wubshet - mamo_wubshet@yahoo.com \\ * Lecturer, Department of Physiotherapy. University of Gondar, College of Medicine and Health Sciences, Department of \\ Physiotherapy, Gondar, Ethiopia \\ ** PhD, Associate Professor of Public Health. University of Gondar, College of Medicine and Health Sciences, Institute of \\ Public Health, Gondar, Ethiopia.
}

\begin{abstract}
Introduction: With the advent of Antiretroviral Therapy (ART), people living with HIV and AIDS (PLWHA) are living longer with chronicity. Reduced physical functioning decreases quality of life of people living with HIV and AIDS. Objective: This study was intended to assess self-reported physical functioning and factors associated with it among adult outpatients living with HIV and AIDS who are on ART at the University of Gondar Hospital HIV Care Clinic. Method: A cross-sectional study was conducted on 313 adults living with HIV and AIDS from March to May 2013. The Short Form-36 physical functioning subscale was used to assess physical functioning. The physical functioning subscale was transformed to range from 0 to a 100 to make all values on same metric, and mean was calculated. Finally normbased scoring method was used to determine whether they have good or poor physical functioning. Result: Total mean score of physical functioning was 59.43 ( $S D=10.7)$. Among 313 participants, 191 $(61 \%)$ reported good physical functioning. More than half of the subjects $(61 \%)$ were independent in work-capacity. Two hundred and nineteen (70\%) individuals were independent in mobility and $96.8 \%$ in self-care. Good physical functioning was associated with $\mathrm{CD}_{4}$ counts $\geq 250$ cells $/ \mathrm{mm} 3[\mathrm{AOR}=1.84$, $95 \% \mathrm{Cl}: 1.02,3.31]$, excellent general health $[\mathrm{AOR}=4.14,95 \% \mathrm{Cl}: 2.12,7.07]$, absent or very mild bodily pain $[\mathrm{AOR}=4.04,95 \% \mathrm{Cl}: 2.03,6.59]$ and high bodily energy [AOR=7.70, $95 \% \mathrm{Cl}: 4.32,8.52]$. Conclusion: This study found that majority of the subjects had good physical functioning and were independent in self-care activities. Higher $\mathrm{CD}_{4}$ counts, vitality, general health and level of mild bodily pain were factors determining physical functioning. This research indicates the need of designing rehabilitation strategies for people living with HIV and AIDS.
\end{abstract}

Keywords: HIV; AIDS; Physical Functioning; Quality of Life. 


\section{BACKGROUND}

The Human Immunodeficiency Virus (HIV) and Acquired Immune Deficiency Syndrome (AIDS) pandemic continues to affect the world. As more infections and death occur, it is considered one of the world's most serious public health problems. ${ }^{(1)}$ According to the Joint United Nations Programme on HIV and AIDS, an estimated 36.7 million people globally were living with HIV and AIDS in the year 2015. (2) Sub-Saharan Africa still carries the highest burden of the disease with nearly 1 in 20 adults. ${ }^{(3)}$

The World Health Organization (WHO) estimated the national prevalence of HIV in Ethiopia in 2014 to be $1.14 \%$, resulting over 769,600 people living with HIV in the same year. ${ }^{(4)}$ Since the virus was first detected in Ethiopia in 1984, it has claimed the lives of millions, ${ }^{(5)}$ and an estimated 339,043 adults and 22, 955 children were receiving antiretroviral therapy (ART) at the end of 2014. ${ }^{(4)}$

Mortality associated with HIV and AIDS has significantly decreased with the introduction of ART. ${ }^{(6,7)}$ Increased survival rates have meant that HIV and AIDS has become a chronic illness. Whilst people living with HIV and AIDS (PLWHA) have been living longer, chronicity has had an impact on their health related quality of life (HRQOL). ${ }^{(8)}$ ART delays progression of HIV and AIDS and the emphasis of treatment has shifted from end-of-life issues to long-term management. $(9,10)$

Previous research has highlighted self-reported impairment, activity limitation and participation restriction among PLWHA, ${ }^{(11)}$ which affected their physical functioning and activities of daily living (ADL). ${ }^{(12)}$

Physical disability related to HIV and AIDS is emerging as an important area of global policy development ${ }^{(9,13)}$ as HIV infection has an impact in physical impairment. ${ }^{(6,14,15)}$ Reduced physical functioning among PLWHA creates dependence in most ADLs, and is often overshadowed. ${ }^{(16)}$

Various literatures show the importance of assessing sociodemographic and clinical characteristics which are closely related to quality of life PLWHA, especially physical functioning. ${ }^{(5,17,18)}$
Although, researches ${ }^{(5,6,14)}$ highlight the emergence of physical disability and impairment among the HIV population, there is limited information on its impact on their quality of life especially on physical functioning and performance of ADLs. With the increased burden of infection and availability of HIV treatment services, assessing physical functioning, functional impairments and factors associated with it among PLWHA is important. (5) Hence, this research was intended to assess physical functioning and factors associated with it among adults living with HIV and AIDS on ART at the University of Gondar Hospital HIV care clinic.

\section{METHODS}

\section{STUDY DESIGN AND SETTING}

This study was an institution based cross-sectional study which was conducted at the University of Gondar Hospital HIV Care Clinic. The February 2013 reports indicated that 3516 adults living with HIV and AIDS were on ART care at the clinic. PLWHA visit the HIV care clinic based on the appointment given to them from the caring physicians.

\section{STUDY POPULATION}

Three hundred and thirteen subjects were included in this study. Sample size was calculated based on single population proportion formula. The required sample size was obtained by the following calculation ( $n=$ sample size, $p=$ prevalence of good physical conditioning, $d=$ margin of error) $n=z^{2} p(1-p) / d^{2}$, $\mathrm{n}=(1.96) 2 \times(0.72)(0.28) /(0.05)^{2}=313$ after adding $10 \%$ contingency. $P=0.72$ was obtained from $a$ thesis undertaken by Tolla $L$ 2006. ${ }^{(19)}$ Every fourth patients attending the clinic were selected and included in the sample using systematic random sampling technique. The study period was between March to May 2013. Inclusion criteria's were: individuals aged 18 or above taking ART for at least 3 months 
preceding data collection period. Ethical clearance was obtained from University of Gondar ethical review committee and informed consent was provided by the participants.

\section{MEASUREMENTS AND VALIDATION OF INSTRUMENT}

The short form (SF-36), physical functioning subscale was used to assess physical functioning. Socio-demographic data and self-reported physical functioning were gathered through an interview. Clinical data such as WHO disease stage, types of regimen, $\mathrm{CD}_{4}$ counts and duration since the start of ART were obtained from the patient's medical chart. The data collection tool was pretested and Chrornbach's $\alpha$ was calculated for all physical functioning subscales, showing $>0.74$ for all scales; 0.76 for self-care, 0.77 for mobility, 0.80 for workcapacity, 0.81 for general health, 0.82 for pain and 0.82 for vitality.

First, the physical functioning subscale was transformed to range from o to a 100. Then Z-score transformation was done to make all values to be on the same metric, resulting mean of 50 and a standard deviation of 10 . Finally, physical functioning was assessed in terms of work-capacity, mobility and self-care, and it was dichotomized to 'good physical functioning' and 'poor physical functioning' by using norm based scoring, where all scale measures are on the same metric, and 50 is the mean and 10 is the standard deviation, which is believed to be easy to decide where the subjects quality of life falls, when

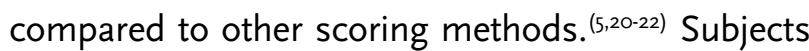
who scored above the mean were considered to have good physical functioning, and poor physical functioning if they score below the mean.

\section{DATA ANALYSIS}

Data analysis was performed using standard statistical software (SPSS version 16 for windows). Frequency tables, percentages, means and standard deviations were used to present the results. Logistic regression was used to study the association between the dependent variable (physical functioning) and independent variables (age, sex, residence, marital status, educational status, employment status, monthly income, CD4 count, WHO disease stage, duration of ART use, type of regimen, vitality, pain, general health). Those variables which were significant at $\alpha=5 \%$ by bivariate analysis were further analysed using multivariate analysis for controlling the confounders.

\section{RESULTS}

\section{SOCIO-DEMOGRAPHIC CHARACTERISTICS OF THE STUDY PARTICIPANTS}

A total of 313 PLWHA who were on ART participated in this study. One hundred and four (33.2\%) were male. Age ranged from 18 to 78 with a mean of 36 $(S D=10.31)$ years.

One hundred and forty three $(45.7 \%)$ were married. Eighty one (25.9\%) participants were uneducated. Eighty-two (26.2\%) were government employees. Over $43.1 \%$ earned a salary of $<12$ USD per month. The majority of the study subjects (93.6\%) lived in urban areas, as shown in table 1. 
Table 1 - Socio-demographic characteristics of PLWHA on ART in University of Gondar Hospital, ART clinic $(\mathrm{N}=313)$ May 2013

\begin{tabular}{|c|c|c|c|c|}
\hline VARIABLES & TOTAL (N) & $\begin{array}{c}\text { GOOD PHYSICAL } \\
\text { FUNCTIONING } \\
\text { N (\%) }\end{array}$ & $\begin{array}{c}\text { POOR PHYSIC AL } \\
\text { FUNCTIONING } \\
\text { N (\%) }\end{array}$ & P-value \\
\hline Age, years & & & & 0.046 \\
\hline$<24$ & 22 & $13(4.2)$ & $9(2.9)$ & \\
\hline $25-34$ & 134 & $91(29.0)$ & $43(13.7)$ & \\
\hline $35-44$ & 93 & $59(18.8)$ & $34(10.9)$ & \\
\hline $45-54$ & 43 & $20(6.4)$ & $23(7.3)$ & \\
\hline $55-64$ & 16 & $5(1.6)$ & $11(3.5)$ & \\
\hline$>65$ & 5 & $3(1.0)$ & $2(0.6)$ & \\
\hline Residence & & & & 0.569 \\
\hline Urban & 293 & $180(57.5)$ & $113(36.1)$ & \\
\hline Rural & 20 & $11(3.5)$ & $9(2.9)$ & \\
\hline Sex & & & & 0.180 \\
\hline Male & 104 & $58(18.5)$ & $46(14.7)$ & \\
\hline Female & 209 & $133(42.5)$ & $76(24.3)$ & \\
\hline Marital status & & & & 0.067 \\
\hline Single & 35 & $25(8.0)$ & $10(3.2)$ & \\
\hline Divorced & 71 & $34(10.9)$ & $37(11.8)$ & \\
\hline Married & 143 & $94(30.0)$ & $49(15.7)$ & \\
\hline Widowed & 64 & $38(12.1)$ & $26(8.3)$ & \\
\hline Educational status & & & & 0.542 \\
\hline Not educated & 81 & $46(14.7)$ & $35(11.2)$ & \\
\hline Grade 1-6 & 48 & $28(8.9)$ & $2 \mathrm{O}(6.4)$ & \\
\hline “ $7-8$ & 40 & $22(7.0)$ & $18(5.8)$ & \\
\hline “ $9-10$ & 38 & $26(8.3)$ & $12(3.8)$ & \\
\hline “ $\quad 11-12$ & 68 & $43(13.7)$ & $25(8.0)$ & \\
\hline$“ \quad>12$ & 38 & $26(8.3)$ & $12(3.8)$ & \\
\hline Employment status & & & & 0.069 \\
\hline Government employee & 82 & $57(18.2)$ & $25(8.0)$ & \\
\hline Private employee & 89 & $54(17.3)$ & $35(11.2)$ & \\
\hline Jobless & 17 & $7(2.2)$ & $10(3.2)$ & \\
\hline Farmer & 8 & $2(0.5)$ & $6(1.9)$ & \\
\hline Student & 7 & $4(1.3)$ & $3(1.0)$ & \\
\hline House wife & 85 & $55(17.6)$ & $30(9.6)$ & \\
\hline Other & 25 & $12(3.8)$ & $13(4.2)$ & \\
\hline Monthly income in USD & & & & 0.078 \\
\hline$<12$ & 135 & $77(24.6)$ & $58(18.5)$ & \\
\hline $12-35$ & 52 & $25(8.0)$ & $27(8.6)$ & \\
\hline $35-59$ & 80 & $56(17.9)$ & $24(7.7)$ & \\
\hline$>59$ & 46 & $33(10.5)$ & $13(4.2)$ & \\
\hline
\end{tabular}




\section{CLINICAL CHARACTERISTICS OF THE STUDY PARTICIPANTS}

Two hundred and fifty one (72.5\%) of subjects had $C_{4}$ counts $\geq 251$ cells $/ \mathrm{mm}^{3}$. The majority of subjects were in the clinical stages I and II (58.1\%) followed by stage III and IV (41.9\%). Most, 93.3\% of patients were on the first line drugs, as shown in table 2.

Table 2 - Clinical characteristics and physical functioning of PLWHA on ART in University of Gondar Hospital, ART clinic (N=313) May 2013

\begin{tabular}{lccc}
\hline \multicolumn{1}{c}{ VARIABLES } & $\begin{array}{c}\text { GOOD PHYSICAL } \\
\text { FUNCTIONING } \\
\text { N (\%) }\end{array}$ & $\begin{array}{c}\text { POOR PHYSICAL } \\
\text { FUNCTIONING } \\
\text { N (\%) }\end{array}$ & P-VALUE \\
\hline $\begin{array}{l}\text { Clinical characteristics CD4 count } \\
.250\end{array}$ & $38(12.1)$ & $48(15.3)$ & $<0.001$ \\
.251 & $153(48.9)$ & $74(23.6)$ & \\
WHO disease stages & $120(38.3)$ & $62(19.8)$ & 0.05 \\
I - II & $71(22.7)$ & $60(19.2)$ & \\
III- IV & & & \\
Duration of ART in Months & $40(12.8)$ & $46(14.7)$ & \\
$<24$ & $151(48.2)$ & $76(24.3)$ & \\
.25 & $177(56.5)$ & $115(36.7)$ & $7(2.2)$ \\
Type of regimen & $14(4.5)$ & 0.584 & \\
First line & & & \\
Second line & & & \\
\hline
\end{tabular}

\section{SELF-REPORTED PHYSICAL FUNCTIONING AND ITS CHARACTERISTICS OF THE STUDY PARTICIPANTS}

The total mean score of physical functioning was 59.43 (SD=10.7). 191 (61\%) participants reported good physical functioning whilst 39\% reported poor physical functioning. All subjects with good physical functioning reported independence in moderate to vigorous activities; such as splitting firewood, lifting heavy objects, moving furniture and washing clothes. With regards to level of independence in mobility, 219 (70\%) participants were independent in climbing stairs or hills, kneeling or bending, lifting light objects and walking the distance of a football field.

Ninety-six percent of participants reported independence in self-care activities such as eating, dressing and bathing.

Forty one percent of the participants reported to have excellent general health. During the last 30 days preceding data collection, $114(36.4 \%)$ subjects experienced "mild to moderate" bodily pain. The majority, 224 (71.6\%) participants reported as "not at all" to "a little bit of work limitation" due to pain. Thirty nine percent of the participants reported to have 'a good bit to some of the time' energy to do various tasks of ADLs such as lifting objects, washing clothes and carrying basket to the market in the last 30 days as shown in table 3 . 
Table 3 - Perceived functionality characteristics of PLWHA on ART in University of Gondar Hospital, ART clinic ( $\mathrm{N}=313)$ May 2013

\section{VARIABLES}

\section{Perceived functionality Vitality}

All - Most of the time

A good bit - Some of the time

A little - None of the time

\section{Bodily pain}

None -very mild

85(27.2)

$66(21.1)$

$4 \mathrm{O}(12.8)$

Severe - Very severe

\section{General health status}

Excellent

87(27.7)

75(24.0)

Very good-good

29(9.3)
$21(6.7)$

49(15.7)

$52(16.6)$

25(8.0)

48(15.3)

$49(15.7)$

$42(13.4)$

15(4.8)

65(20.8)

\section{FACTORS ASSOCIATED WITH PHYSICAL FUNCTIONING}

CD4 counts of $\geq 251$ cells $/ \mathrm{mm}^{3}$, excellent general health, "none to mild pain", and vitality ranging from "all of the time to most of the time" was significantly associated with good physical functioning in this study, as shown in table 4.

Table 4 - Factors associated with physical functioning among PLWHA who are on ART by multivariate and bivariate logistic regression ( $\mathrm{N}=313)$, May 2013

\begin{tabular}{|c|c|c|c|c|c|}
\hline VARIABLES & GOOD, POOR & $\begin{array}{c}\text { PHYSICAL } \\
\text { FUNCTIONING }\end{array}$ & $\begin{array}{c}\text { CRUDE OR } \\
(95 \% \mathrm{Cl}) \\
\mathrm{N}\end{array}$ & $\begin{array}{c}\text { ADJUSTED OR } \\
(95 \% \mathrm{Cl}) \\
\mathrm{N}\end{array}$ & P VALUE \\
\hline CD4 counts cells/mm3 & & & & & 0.042 \\
\hline .250 & 38 & 48 & 1 & 1 & \\
\hline .251 & 153 & 74 & $2.6(1.57,4.34)$ & 1.8(1.O2, 3.31) & \\
\hline WHO stage & & & & & 0.173 \\
\hline$|-| \mid$ & 120 & 62 & 1.6(1.03, 2.59) & $1.5(0.83,2.72)$ & \\
\hline III-IV & 71 & 60 & 1 & 1 & \\
\hline Duration of ART, months & & & & & 0.578 \\
\hline$<24$ & 40 & 46 & 1 & 1 & \\
\hline .25 & 151 & 76 & $2.2(1.37,3.78)$ & $1.2(0.61,2.39)$ & \\
\hline
\end{tabular}


Table 4 - Factors associated with physical functioning among PLWHA who are on ART by multivariate and bivariate logistic regression ( $\mathrm{N}=313)$, May 2013

\begin{tabular}{|c|c|c|c|c|c|}
\hline \multirow[b]{2}{*}{ VARIABLES } & & & & & (conclusio \\
\hline & GOOD, POOR & $\begin{array}{c}\text { Physical } \\
\text { Functioning }\end{array}$ & $\begin{array}{c}\text { CRUde OR } \\
(95 \% \mathrm{Cl}) \\
\mathrm{N}\end{array}$ & $\begin{array}{c}\text { ADJUSTED OR } \\
(95 \% \mathrm{Cl}) \\
\mathrm{N}\end{array}$ & P VALUE \\
\hline Gener al health & & & & & $<0.001$ \\
\hline Excellent & 87 & 42 & $4.6(2.62,8.22)$ & $4.1(2.12,7.07)$ & \\
\hline Very good Î good & 75 & 15 & $11.2(5.53,22.71)$ & $12.2(5.54,12.9)$ & \\
\hline Fair - poor & 29 & 65 & 1 & & \\
\hline Bodily pain & & & & & $<0.001$ \\
\hline None Î very mild & 85 & 25 & $4.1(2.26,7.67)$ & $4.0(2.03,6.59)$ & \\
\hline Mild Î moderate & 66 & 48 & $1.6(1.96,2.94)$ & $1.5(1.31,2.24)$ & \\
\hline Severe Î very severe & 40 & 49 & 1 & 1 & \\
\hline Vitality & & & & & $<0.001$ \\
\hline $\begin{array}{l}\text { All of the time- } \\
\text { most of }\end{array}$ & 93 & 21 & $10(5.062,19.803)$ & $7.7(4.32,8.52)$ & \\
\hline \multicolumn{6}{|l|}{ The time } \\
\hline $\begin{array}{l}\text { A good bit - some } \\
\text { of the }\end{array}$ & 75 & 49 & $3.4(1.883,6.361)$ & $3.0(1.60,5.62)$ & \\
\hline \multicolumn{6}{|l|}{ Time } \\
\hline $\begin{array}{l}\text { A little Î None of } \\
\text { the time }\end{array}$ & 23 & 52 & & 1 & \\
\hline
\end{tabular}

\section{DISCUSSION}

This study revealed that, 191 (61\%) participants reported good physical functioning while 122 (39\%) reported poor physical functioning. Those participants with poor physical functioning described different levels of difficulty in completing certain tasks of ADLs. This finding is comparable with studies done in America ${ }^{(8,10)}$ on PLWHA, where the proportion of activity limitation due to poor physical health ranges from $19-51 \%$. The commonly reported limitations were related to activities requiring substantial exertion, heavy house work. ${ }^{(8,10)}$

Ninety four (30\%) of the individuals in our study, reported different levels of dependency including stair or hill climbing and walking. This finding is consistent with the previous study, ${ }^{(23)}$ where $26 \%$ PLWHA showed limitation of mobility. This could possibly be explained by the aerobic dysfunction among PLWHA which could limit their physical performance. ${ }^{(24)}$
In both a bivariate and multivariate analysis, none of the socio-demographic variables were significantly associated with physical functioning. Our finding is similar to a study carried out in London, UK on fatigue among HIV-infected patients in the era of ART, in which no association was found between physical health and demographic characteristics. ${ }^{25)}$

The present study found that a higher $\mathrm{CD}_{4}$ count was associated with good physical functioning. This finding is in agreement with the studies carried out in Southern Ethiopia, (5) Malaysia, ${ }^{(6)}$ USA $^{(8)}$ and Estonia. ${ }^{(26)}$ Higher levels of opportunistic infection and disability, which reduces general health was observed among PLWHA with low CD4 counts, which would further reduce the person's ability to participate in ADL. ${ }^{(10,13,24,27)}$

In our study, a significant association was seen between the level of body energy and physical functioning. This finding is similar to other studies, $(7,23,25,28-30)$ where authors declared fatigue, 
extreme levels of tiredness or low vitality impeded the patient's ability to perform physical tasks.

'Absence' or 'very mild' bodily pain was significantly associated with good physical functioning in PLWHA. This finding is comparable with the study carried out in the USA, ${ }^{(10)}$ and São Paulo, Brazil.(31) In both studies, it was concluded that pain interfered with walking and with other ADLs. Neuropathic pain was among the common complaints amongst individuals with the advanced HIV.(31)

General health was significantly associated with physical functioning, which is in agreement with previous studies. ${ }^{(8,9,10,18,20,24)}$ Factors, such as fatigue, fever and anaemia, ${ }^{(10)}$ lower $\mathrm{CD}_{4}$ counts, pain, ${ }^{(8-10)}$ different co-morbidities and opportunistic infections due to the virus and physiologic deconditioning ${ }^{(27)}$ were all related to poor general health among PLWHA. Sicker PLWHA are less able to actively perform work-related tasks, hence reduced physical functioning.

In contrast to the previous study, ${ }^{\left({ }^{22}\right)}$ this study did not show any association between the disease stage and physical functioning ( $\mathrm{P}=0.173)$. This finding is consistent with research carried out in USA ${ }^{(20)}$ and UK. ${ }^{25)}$ The Possible explanation for this difference include lack of stratifying participants equally into different disease stages during data collection. In addition, there is also a difference in time between duration of disease classification and the time of data collection. Disease classification is carried out every six months in our setup, whilst the current study assessed the physical functioning of the past month only.

Similarly, this study did not find an association between types of regimen used and physical functioning both in a bivariate and multivariate analysis. This finding is supported by Henderson et al 2005, ${ }^{(25)}$ where the use of ART was not associated with fatigue and physical functioning.

Lack of proportionally stratifying subjects based on their clinical data such as WHO disease stage and type of regimen, and the retrospective data collection of clinical characteristics from their medical chart which may not represent their past 30 days physical functioning are limitations of this study.

\section{CONCLUSION}

In conclusion, the majority of the subjects reported good physical functioning and were independent in self-care activities. However, $30 \%$ of the subjects reported different levels of dependence in mobility. It is imperative to regularly assess the patients $\mathrm{CD}_{4}$ counts, general health, level of pain and energy during care of PLWHA, to improve their physical functioning.

Further Longitudinal research can be conducted to better study association between the factors and physical functioning among PLWHA.

Actively engaging PLWHA in exercise programs may also be important to improve their physical functioning. ${ }^{(28)}$

\section{COMPETING INTERESTS}

The authors have no competing interests.

\section{ACKNOWLEDGEMENTS}

We would like to acknowledge the University of Gondar research and community core process for funding this research and the subjects who participated in this study.

\section{REFERENCES}

1. Steinbrook R. The AIDS Epidemic in 2004. N Engl J Med. 2004;351(2):115-7. PubMed PMID: 15247349 .

2. UNAIDS. FACT SHEET 2O16. GLOBAL STATISTICS. [cited 2016 June 8]. Avaliable from: http://www.unaids.org/en/resources/fact-sheet

3. World Health Organization. Global Health Observatory data 2015. [cited 2015 June]. Avaliable from: http://www.who.int/gho/hiv/en/

4. World Health Organization . Ethiopia | HIV/ AIDS 2015. [cited 2016 June 8]. Avaliable from: http://www.afro.who.int/en/ethiopia/country programmes/topics/4480-hivaids.html 
5. Abede K, Gedif T, Engidawork E, Gebre-Marian T. Quality of Life of People Living with HIV/AIDS and on Highly Active Antiretroviral Therapy in Ethiopia. Afr J AIDS Res April 201O[cited 2011 July 14];9(1):31-4O. Avaliable from: https://www. researchgate.net/publication/230874556_ Quality_of_Life_of_People_Living_with_HIVAI

6. Hasanah $\mathrm{Cl}$, Zaliha AR, Mahiran M. Factors influencing the quality of life in patients with HIV in Malaysia. Qual Life Res. 2011 [cited 2011 Jul 18];2O(1):91-100. doi: 10.1007/s11136-0109729-y. Epub 2010 Aug 26.

7. $\mathrm{PMöller} \mathrm{PH,} \mathrm{Smit} \mathrm{R.} \mathrm{Measuring} \mathrm{health-related}$ quality of life: a comparison between people living with aids and police on active duty. Afr J AIDS Res 2004 [cited $2011 \mathrm{Jul}$ 10];9(2):31-42. Avaliable from: http://www.ajol.info/index.php/ hsa/article/viewFile/1O249/2337

8. McDonnell KA, Gielen AC, Wu AW, O'Campo $P$, Faden R. Measuring health related quality of life among women living with HIV. Qual Life Res. 2006 [cited 2011Jul 19]; 9(8): 931-940. Avaliable from: http://link.springer.com/article/1 0.1023\%2FA\%3A1008909919456

9. Huanguang J, Constance RU, Arnp-BC, Faan, Samuel W, John chen, et al. Predictors of changes in health-related quality of life among men with HIV infection in the HAART era. AIDS Patient Care STDS 2005 [cited 2O11Jul 15]; 19(6): 395-405. Avaliable from: https:// www.researchgate.net/publication/7755467. Predictors_of_changes_in_healthrelated_quality_ of_life_among_men_with_HIV_infection_in_the HAART_era

1O. Vosvick M, Koopman C, Gore-Felton C, Thoresen C, Krumboltz J, Spiegel D. Relationship of functional quality of life to strategies for coping with the stress of living with HIV/ AIDS. Psychosomatics. 2003 [cited 2011Jul 17];44(1):51-8. Avaliable from: http://www.ncbi. nlm.nih.gov/pubmed/12515838

11. Roubenoff R, Wilson IB. Effect of Resistance Training on Self-Reported Physical Activity Functioning in HIV Infection. Med Sci Sports Exerc. 2001;33(11):1811-1817. [PubMed]
12. Briongos Figuero LS, Bachiller Luque P, Palacios Martín T, González Sagrado M, Eiros Bouza JM. Assessment of factors influencing health-related quality of life in HIV-infected patients. HIV Med. 2011 [cited 2011 July 16];12(1):22-30j.1468-1293. Avaliable from: http://www.ncbi.nlm.nih.gov/ pubmed/2O497251

13. Elliott R, Utyasheva L, Zack E. HIV, disability and discrimination: making the links in international and domestic human rights law. J Int AIDS Soc. 2009 [cited 2011 July 16]; 12:29. Avaliable from: http://www.ncbi.nlm.nih.gov/pmc/articles/ PMC2788342/

14. United Nations Human Rights, World Health Organization, United Nations High Commissioner for Human Rights. Disability and HIV Policy Brief. 2009. [cited 2011 July 15]. Avaliable from: http://www.who.int/disabilities/ jc1632_policy_brief_disability_en.pdf

15. Louwagie G, Bachmann M, Meyer K, Booysen F, Fairall L, Heunis $C$. Highly active antiretroviral treatment and health related quality of life in South African adults with human immunodeficiency virus infection: A crosssectional analytical study. BMC Public Health. 2007 [cited 2011 July 17];7(244):1-10. Avaliable from: http://www.biomedcentral.com/1471$2458 / 7 / 244$

16. Rusch M, Nixon S, Schilder A, Braitstein P, Chan K, Hogg RS. Prevalence of activity limitation among persons living with HIV/AIDS in British Columbia. Can J Public Health 2004 [cited 2013 Jan 13]; 95(6): 437-40. Avaliable from: http://www.ncbi.nlm.nih.gov/pubmed/15622793

17. Briongos Figuero LS, Bachiller Luque P, Palacios Martín T, González Sagrado M, Eiros Bouza JM. Assessment of factors influencing healthrelated quality of life in HIV-infected patients. HIV Med. 2011 [cited 2015 June 5];12(1):22-30. Avaliable from: http://www.ncbi.nlm.nih.gov/ pubmed/20497251

18. Doris M, Achilles K, Faith M, Janet S, Albert W. Factors That Affect Quality of Life among People Living with HIV Attending an Urban Clinic in Uganda: A Cohort Study. PLoS ONE. 2015 (cited 2015 July 10];1O(6):eO126810. Avaliable from: http://journals.plos.org/plosone/ article?id=10.1371/journal.pone.0126810 
19. Tolla L. Assessing the quality of life (QOL) of people living with HIV/AIDS on highly active antiretroviral therapy in Zenebework Hospital, Addis Ababa. Abstracts of the XVIlth Annual Conference of the Ethiopian Public Health Association; Harar, Ethiopia; 2006. Abstract no.71

20. Garber C, Greaney ML, Riebe D, Nigg CR, Burbank PA, Clark PG. Physical and mental health-related correlates of physical function in community dwelling older adults: a cross sectional study. BMC Geriatr. 2010 [cited 2012 May 15]; 1O(6). Avaliable from: http://www. biomedcentral.com/1471-2318/10/6

21. Vidrine DJ, Amick BC 3rd, Gritz ER, Arduino RC. Functional status and overall quality of life in a multiethnic HIV-positive population. AIDS Patient Care STDS. 2003 [cited 2012 May 12];17(4):187-97. Avaliable from: doi: 10.1089/108729103321619791 [PubMed]

22. Ware JEJ. SF-36 Health Survey Update. Spine. 2000;25(24):3130-9. PubMed PMID: 00007632-200012150-00008. Avaliable from: http://journals.lww.com/spinejournal/ Fulltext/2000/12150/SF_36_Health_Survey_ Update.8.aspx

23. Crystal S, Fleishman JA, Hays RD, Shapiro MF, Bozzette SA. Physical and role functioning among persons with HIV: results from a nationally representative survey. Med Care 2000 [2012 June 3]; 38(12):1210-23. Avaliable from: http://www.ncbi.nlm.nih.gov/ pubmed/11186300

24. Cade WT, Peralta L, Keyser RE. Aerobic Exercise Dysfunction in Human Immunodeficiency Virus: A Potential Link to Physical Disability. Phys Ther. 2004 [2012 June 4]; 84(655-664). Avaliable from: http://ptjournal.apta.org/content/84/7/655. full.pdf+html

25. Henderson M, Safa F, Easterbrook P, Hotopf M. Fatigue among HIV-infected patients in the era of highly active antiretroviral therapy. HIV Med. 2005 [2012 June 7];6(5):347-52. Avaliable from: http://onlinelibrary.wiley.com/doi/10.1111/ j.1468-1293.2005.00319.x/epdf
26. Kristi R, Heti P, Helle-Mai L, Anneli U. Factors influencing quality of life of people living with HIV in Estonia: a cross-sectional survey. J Int AIDS Soc. 2009 [2011 July 17]; 12(13). Avaliable from: http://www.ncbi.nlm.nih.gov/pmc/articles/ PMC2717916/

27. Marcellin F, Préau M, Ravaux I, Dellamonica P, Spire B, Carrieri MP. Self-reported fatigue and depressive symptoms as main indicators of the quality of life (QOL) of patients living with HIV and Hepatitis C: implications for clinical management and future research. HIV Clin Trials. 2007 [2011 July 15];8(5):320-7. Avaliable from: http://www.ncbi.nlm.nih.gov/ pubmed/17956833

28. Siegel K, Brown-Bradley CJ, Lekas H-M. Strategies for Coping with Fatigue Among HIV-Positive Individuals Fifty Years and Older. AIDS Patient Care STDS. 2004 [2012 May 25];18(5):275-88. Avaliable from: http://www. ncbi.nlm.nih.gov/pubmed/15186711

29. Nokes K, Holzemer W, Corless I, Bakken S, Brown $M$, et al. Health related quality of life in persons younger and older than 50 who are living with HIV and AIDS. Res Aging. 2000 [2011 July 13]; 22(3):290-310. Avaliable from: http://bvs.insp. $\mathrm{mx} /$ articulos/2/25/O2032001.pdf

30. Bolge SC, Mody S, Ambegaonkar BM, McDonnell DD, Zilberberg MD. The impact of anemia on quality of life and healthcare resource utilization in patients with HIV/AIDS receiving antiretroviral therapy. Curr Med Res Opin. 2007 [cited 2012 Mar 25];23(4):803-10. Avaliable from: http://www.ncbi.nlm.nih.gov/ pubmed/17407637

31. Fragoso YD, Mendes V, Adamo APM, Bosco LP, Tavares CAF. Neurologic manifestations of AIDS: a review of fifty cases in Santos. Sao Paulo Med J. [2O12 May 25]. 1998;116(3). Avaliable from: http://www.scielo.br/scielo.php?script=sci_ arttext\&pid=\$1516-31801998000300005

32. Phillips KD, Sowell RL, Rojas M, Tavakoli A. Physiological and psychological correlates of fatigue in HIV/AIDS. Bio Res Nurs. 2004 [2012 May 30]; 6(1):59-74. 